\title{
PENERAPAN METODE ANALOGY BIOMIMICRY PADA PERANCANGAN KLINIK TUBERKULOSIS PARU DI SURABAYA.
}

\author{
Jarot Wahyono \\ Dosen Prodi Arsitektur, Fak. Teknik Sipil dan Perencanaan, ITN Malang \\ e-mail: jarotwahyono@lecturer.itn.ac.id \\ Amar Rizqi Afdholy \\ Dosen Prodi Arsitektur, Fak. Teknik Sipil dan Perencanaan, ITN Malang \\ e-mail: amarrizqi@lecturer.itn.ac.id
}

\begin{abstract}
ABSTRAK
Indonesia sebagai negara urutan ke 2 tertinggi dunia untuk kasus tuberculosis (Global Tuberculosis Report,2016). Faktor peningkatan kasus tuberkulosis ialah terbatasnya fasilitas pelayanan kesehatan masyarakat. Penderita tuberkulosis melakukan perawatan kesehatan di klinik kesehatan, namun anggaran dasar dari klinik yang terbatas membuat kelengkapan fasilitas pencegahan penyakit menular sangat kurang (Curry International Tuberculosis Center, 2011). Agar pencegahan penyakit menular pada klinik dapat ditingkatkan dengan menggunakan anggaran yang terbatas, maka aspek alam sebagai strategi pasif pada bangunan akan dimanfaatkan secara maksimal pada bangunan.

Biomimicry menggunakan strategi yang ada di lingkungan/alam untuk digunakan sebagai solusi dari permasalahan yang muncul pada bangunan. Metode perancangan Analogy muncul sebagai panduan dalam proses transfer nilai-nilai yang ada di alam sebelum digunakan sebagai solusi pada bangunan, serta ditambahkan dengan metode Descriptive Model dari Nigel cross yang dapat mendukung proses analisa permasalahan yang akan di selesaikan dengan konsep dari alam.

Proses perancangan akan menghasilkan konsep dan skematik rancangan dari klinik kesehatan dengan menggunakan konsep alam sebagai solusi dalam mengatasi permasalahan yang timbul dalam bangunan, sehingga dapat mengurangi faktor penularan virus tuberculosis pada area klinik kesehatan dan masyarakat sekitar klinik.. Konsep tersebut dapat diaplikasikan pada fasilitas kesehatan lain, sehingga dapat mendukung mengurangi resiko penularan pada klinik kesehatan.
\end{abstract}

Kata kunci : Tuberkulosis Paru-paru, klinik, Biomimicry, metode desain analogi.

PAWON: Jurnal Arsitektur, Nomor 01 Volume VI, Januari - Juni Tahun 2022, ISSN 2597-7636 


\begin{abstract}
Indonesia is the 2nd highest country in the world for tuberculosis cases (Global Tuberculosis Report, 2016). Factors increasing cases of tuberculosis is the limited public health service facilities. Tuberculosis patients perform health care in health clinics, but the limited budget of the clinic makes the completeness of infectious disease prevention facilities very lacking (Curry International Tuberculosis Center, 2011). For the prevention of infectious diseases in clinics to be increased by using a limited budget, the natural aspect as a passive strategy in buildings will be utilized optimally in buildings.

Biomimicry uses strategies that exist in the environment/nature to be used as solutions to problems that arise in buildings. The Analogy design method appears as a guide in the process of transferring values that exist in nature before being used as a solution in buildings and added with the Descriptive Model method from Nigel cross which can support the problem analysis process that will be solved with concepts from nature.

The design process will produce concepts and schematic designs from health clinics using the concept of nature as a solution in overcoming problems that arise in the building, to reduce the transmission factor of the tuberculosis virus in the health clinic area and the community around the clinic. This concept can be applied to other health facilities so that it can help reduce the risk of transmission in health clinics.
\end{abstract}

\title{
Keywords : Pulmonary Tuberculosis, clinic, Biomimicry, analogy design method
}

\section{PENDAHULUAN}

\subsection{Latar Belakang}

Indonesia adalah negara urutan kedua pada jumlah kasus positif penyakit tuberkulosis paru dunia (Global Tuberculosis Report,2016). Data tersebut menerangkan bahwa $10 \%$ penderita tuberkulosis dunia ada di Indonesia. Dengan penderita tuberkulosis baru 331.119 orang dan kematian 100.000 orang pada 2015. Angka kematian tersebut mencapai 40 orang meninggal setiap 100.000 penduduk Indonesia secara keseluruhan.

Minimnya fasilitas kesehatan yang mendukung pencegahan penyakit tuberkulosis di Indonesia merupakan faktor penyebab peningkatan kasus tersebut, terutama pada fasilitas klinik kesehatan. Pasien yang belum sadar bahwa dirinya positif tuberculosis yang berada di klinik, secara bebas mengabaikan aspek penularan penyakit tersebut, sehingga bakteri tuberkulosis mencemari klinik tersebut. Ditambah lagi fasilitas yang ada di klinik terkait pencegahan penyakit menular sangat terbatas (Curry

PAWON: Jurnal Arsitektur, Nomor 01 Volume VI, Januari - Juni Tahun 2022, ISSN 2597-7636 
International Tuberculosis Center,2011). Terbatasnya fasilitasn untuk mencegah penyakit menular dalam kawasan klinik kesehatan membuat area tersebut menjadi rentan terhadap penularan bakteri tuberkulosis.

Diperlukan banyak perangkat pendukung untuk mengoptimalkan pencegahan penularan penyakit dalam area klinik yang berdampak pada besarnya anggaran yang dibutuhkan oleh klinik tersebut, sedangkan anggaran yang dimiliki oleh klinik sangat terbatas. Strategi pasif dengan memanfaatkan konsep alam digunakan untuk mendukung penyebaran bakteri tuberkulosis dalam area klinik dengan menggunakan anggaran yang terbatas.

Konsep biomimicry melakukan pengembangan dari ide inspiratif alam dan melakukan penyesuaian terhadap ide tersebut untuk membuat solusi dari permasalahan perancangan. Hewan, tumbuhan dan mikroba adalah insinyur terampil. Mereka telah menemukan sesuatu yang berhasil, sesuatu yang pantas dan yang paling penting, sesuatu yang berlangsung di bumi (Benyus,1997). Biomimicry membantu menyelesaikan masalah yang timbul dalam klinik kesehatan tuberkulosis paru dengan memanfaatkan ide inspiratif dari alam.

Kriteria khusus perancangan yang muncul sebagai aspek permasalahan dalam proses perancangan antara lain adalah aspek penghawaan (aliran udara), aspek suhu, aspek pencahayaan alami dan aspek dekoratif. Penggunaan konsep biomimicry dengan metode perancangan analogi dalam menyelesaikan permasalahan perancangan memuat proses analisa yang akan menghasilkan konsep penyelesaian masalah dari permasalahan utama perancangan.

Pada aspek suhu menggunakan analogi tumbuhan parasit pada bangunan, pada aspek pencahayaan alami menggunakan analogi bentuk kelopak bunga dan analogi kulit durian, serta pada aspek dekoratif digunakan analogi ekosistem hutan secara langsung.

\subsection{Lokasi Perancangan}

Lokasi perancangan dari klinik tuberkulosis paru berada pada kecamatan Semampir Surabaya. Kecamatan Semampir memiliki perbandingan luas kawasan dan jumlah fasilitas kesehatan yang lebih minim dibandingkan dengan kecamatan lain di Surabaya. Daerah dengan penyebaran dan kasus positif tuberkulosis tertinggi di Surabaya pada 2012 antara lain kecamatan Sawahan, Wonokromo, Tambaksari dan Semampir (Yahya, 2012). Berdasarkan luas area dan jumlah fasilitas keesehatan yang ada pada area tersebut, sehingga kecamatan Semampir dipilih sebagai lokasi perancangan klinik kesehatan tuberkulosis paru. Diharapkan dengan adanya klinik tersebut, dapat meningkatkan penanggulangan penyakit tuberkulosis pada area tersebut.

PAWON: Jurnal Arsitektur, Nomor 01 Volume VI, Januari - Juni Tahun 2022, ISSN 2597-7636 
Tabel 1:

Data Luasan kecamatan \& Jumlah Fasilitas Kesehatan di Surabaya

\begin{tabular}{|c|c|c|c|c|}
\hline No & Kecamatan & $\begin{array}{c}\text { Luas Area } \\
\left(\mathrm{KM}^{2}\right)\end{array}$ & Fasilitas Kesehatan Sekitar Area & $\begin{array}{c}\text { Jumlah } \\
\text { Fasilitas } \\
\text { Kesehatan }\end{array}$ \\
\hline \multirow[t]{4}{*}{1} & Semampir & 8,76 & Rumah Sakit PHC surabaya & \multirow{4}{*}{4} \\
\hline & & & Rumah Sakit PKU Muhammadiyah & \\
\hline & & & Rumah Sakit Al-Irsyad & \\
\hline & & & Rumah Sakit Paru Surabaya & \\
\hline \multirow[t]{5}{*}{2} & Tambaksari & 8,99 & RSUD Dr. Soetomo & \multirow{5}{*}{5} \\
\hline & & & RS Husada Utama & \\
\hline & & & RS DR M Soewandhie & \\
\hline & & & RS Adi Husada & \\
\hline & & & RS Mitra Keluarga Kenjeran & \\
\hline \multirow[t]{6}{*}{3} & Wonokromo & 8,47 & RSAL Surabaya & \multirow{6}{*}{6} \\
\hline & & & RSU Bhakti Rahayu & \\
\hline & & & RS Darmo & \\
\hline & & & RS Pura raharja & \\
\hline & & & RS William Booth Surabaya & \\
\hline & & & RS Siloam Surabaya & \\
\hline \multirow[t]{4}{*}{4} & Sawahan & 6,93 & RS Darmo & \multirow{4}{*}{4} \\
\hline & & & RS William Booth Surabaya & \\
\hline & & & RS Brawijaya & \\
\hline & & & RS Mitra Keluarga Surabaya & \\
\hline
\end{tabular}

\section{TINJAUAN PUSTAKA}

\subsection{Klinik Tuberkulosis Paru}

Klinik merupakan fasilitas pelayanan kesehatan yang melaksanakan pelayanan pada aspek kesehatan bagi perorangan dengan menyediakan pelayanan medis dasar dan/atau spesialistik (Permenkes No 9 tahun 2014). Jenis pelayanan klinik dibagi menjadi:

a. Klinik pratama: Klinik yang melaksanakan pelayanan dasar dan umum.

b. Klinik utama: Klinik melaksanakan pelayanan spesialistik atau pelayanan dasar \& spesialistik.

Syarat lain yang harus disediakan klinik yaitu komponen bangunan dari klinik yang permanen dan terpisah secara fisik dengan bangunan

PAWON: Jurnal Arsitektur, Nomor 01 Volume VI, Januari - Juni Tahun 2022, ISSN 2597-7636 
tempat tinggal milik perorangan. Komponen hak milik klinik dapat berasal dari pihak pemerintah pusat, pihak pemerintah dalam lingkup daerah, atau masyarakat secara umum. Pada klinik yang menyediakan fasilitas rawat jalan dapat berasal dari perorangan atau kepemilikan oleh badan usaha, sedangkan klinik dengan fasilitas rawat inap dikelola dan berasal dari badan hukum. Rasio kebutuhan dari pelayanan kesehatan dan jumlah penduduk menjadi faktor persebaran klinik yang ditetapkan oleh pemerintah daerah dalam linkup kabupaten atau kota.

Tuberculosis merupakan penyakit yang dapat menular secara langsung dan disebabkan kuman mycobacterium tuberculosis. Kuman tuberkulosis dapat menyerang organ tubuh manusia, antara lain paru-paru, kulit, usus, ginjal, selaput otak dan tulang. Kasus terbesar tuberkulosis dominan menyerang paru-paru manusia karena kuman tuberkulosis dapat menular melalui udara, sehingga perkembangan kuman tuberculosis sering terjadi di paru-paru manusia (Aditama,1994). Aspek khusus pada kuman mycobacterium tuberculosis adalah:

1. Kuman tuberkulosis dapat mati apabila terpapar sinar matahari secara langsung, sedangkan pada area lembab dan gelap dapat bertahan hidup selama beberapa jam. Kuman tuberkulosis mampu tertidur lama (dorman) dalam jaringan tubuh manusia dal,am jangka waktu beberapa tahun (Depkes RI,2002).

2. Kuman tuberkulosis dapat berkembang dengan maksimal pada suhu $22^{\circ} \mathrm{C}$ (Jawetz,1982) dengan jangka waktu berkembang biak kurang lebih 12 jam.

3. Kuman tuberkulosis dapat mati apabila berada pada air yang mendidih dengan suhu $80^{\circ} \mathrm{C}$ selama 5 menit dan dapat mati pada air bersuhu $60^{\circ} \mathrm{C}$ selama 20 menit. Bakteri tuberkulosis dapat bertahan selama berbulan-bulan dengan suhu lembab(Tanjung,2010).

Berdasarkan data departemen kesehatan republik Indonesia (2008), Penularan kuman tuberkulosis memiliki karakter sebagai berikut:

1. Pasien Positif Tuberkulosis merupakan sumber penularan utama kuman tuberkulosis.

2. Pasien positif tuberkulosis mengeluarkan percikan dahak ketika bersin dan batuk, sehingga melepaskan kuman tuberkulosis ke udara.

3. Penularan sering terjadi pada ruangan tertutup yang memungkinkan kuman tuberkulosis dapat menetap pada ruangan tersebut pada waktu tertentu. Adanay pergerakan udara melalui ventilasi ruang dapat mengurangi resiko penularans ementara paparan sinar matahari secara langsung dapat membunuh kuman tuberkulosis.

4. Skala penularan dari pasien positif depengaruhi oleh jumlah kuman yang keluar dari paru-paru penderita tuberkulosis. 
5. Kemungkingan tertular kuman tuberkulosis pada sesorang dipengaruhi oleh jumlah percikan dahak yang ada di udara sekitar individu dan jangka waktu individu tersebut menghirup percikan dahak tersebut.

\subsection{Biomimicry}

Biomimicry melakukan pengembangan ide inspiratif dari lingkungan alam dan melakukan penyesuaian terhadap ide tersebut untuk membuat solusi dari permasalahan perancangan. Aspek ide inspiratif alam tersebut yang membedakan biomimicry dengan konsep hijan yang lain. Hewan, tumbuhan dan mikroba adalah insinyur terampil. Mereka telah menemukan sesuatu yang berhasil, sesuatu yang pantas dan yang paling penting, sesuatu yang berlangsung di bumi (Benyus, 1998)

Konsep dan ide dari alam menerapkan strategi khusus dalam bertahan hidup yang telah melalui berbagai pengujian alami oleh lingkungan yang berlangsung dalam jangka waktu yang lama, sehingga konsep dan ide inspiratif tersebut merupakan hasil adaptasi bertahan hidup yang telah teruji. (Biomimetic Design Method for Innovation and Sustainability,2016).

Beberapa mekanisme biologis ditiru secara langsung (Cohen,2016). Biomimicry memiliki konteks meniru aspek khusus yang berasal dari alam untuk digunakasan sebagai solusi permasalahan yang dihadapi. Aspek mimicing/meniru dilakukan agar penyelesaian masalah dalam proses perancangan dapat membandingkan aspek alam (solusi) dan aspek arsitektur (permasalahan) untuk mendapatkan solusi yang sesuai dan tepat..

Menurut Cohen (2016), terdapat 2 jenis pendekatan dalam metode aalogy biomimicry, antara lain:

\section{Biomimetic Design Process Stages_From a Problem to Biology}

Proses dimulai dengan menetukan permasalahan yang akan diselesaikan, kemudian mencari solusi dari konsep organisme yang ada di alam untuk menyelesaikan permasalahan tersebut.

2. Biomimetic design process stages-from biology to an application

Proses dimulai dengan menentukan konsep organisme yang ada di alam, kemudian mencari potensi masalah yang dapat diselesaikan dengen menggunakan konsep tersebut.

Biomimicry dibagi menjadi tiga kategori (level) yaitu organisme, perilaku dan ekosistem (Zari, 2007). Dimensi peniruan/mimiking muncul pada 3 tingakatan (level) tersebut. Sifat biomimetik pada sebuah rancangan bangunan dapat mengambil konsep alam berupa bentuk (form), cara kerja (proses), bagaimana design tersebut dibuat 
(konstruksi), bahan (material)atau apa yang bisa dilakukan oleh desain tersebut (fungsi).

\section{METODE PENELITIAN}

Tahapan yang dilakukan dalam proses peranccangan bangunan dibagi menjadi 2 tahapan utama yaitu Tahap penelitian dengan metode kualitatif (Descriptive model) dari Nigel Cross, serta tahap perancangan menggunakan metode biomimetic yang didukung oleh proses perancangan analogy dari Cohen (2016) dengan menggunakan alur pengembangan proses yang dimulai dengan analisa permasalahan menuju aspek biologi.

Metode penelitian dari Nigel Cross difungsikan sebagai komponen analisa permasalahan pada tahap awal perancangan. Permasalahan yang muncul akan mempermudah proses perancangan pada tahap selanjutnya.

Tahapan penelitian dari French dijabarkan menjadi 5 tahapan utama (Nigel Cross, 1994):

- Analysis of problem

- Conceptual design

- Embodiement of schemes

- Detailing

- Working

Biomimicry dijabarkan sebagai proses analogical transfer dari pengetahuan perancangan, antara biologi (Source) dan teknologi (target), atau aspek lain dalam teknologi. Desain biomimetic yang digunakan dalam proses transfer analogi proses yang dimulai dengan analisa permasalahan yang muncul, kemudian dihubungkan dengan biologi sebagai solusi dari penyelesaian tersebut.

Tahapan yang berlangung dalam proses perancangan antar lain:

- Problem definition

- Biomimetic problem definition

- Identify analogy source

- Abstraksi design solustion

- Transfer solution to biomimetic aplication or concept

- Evaluation \& iteration 


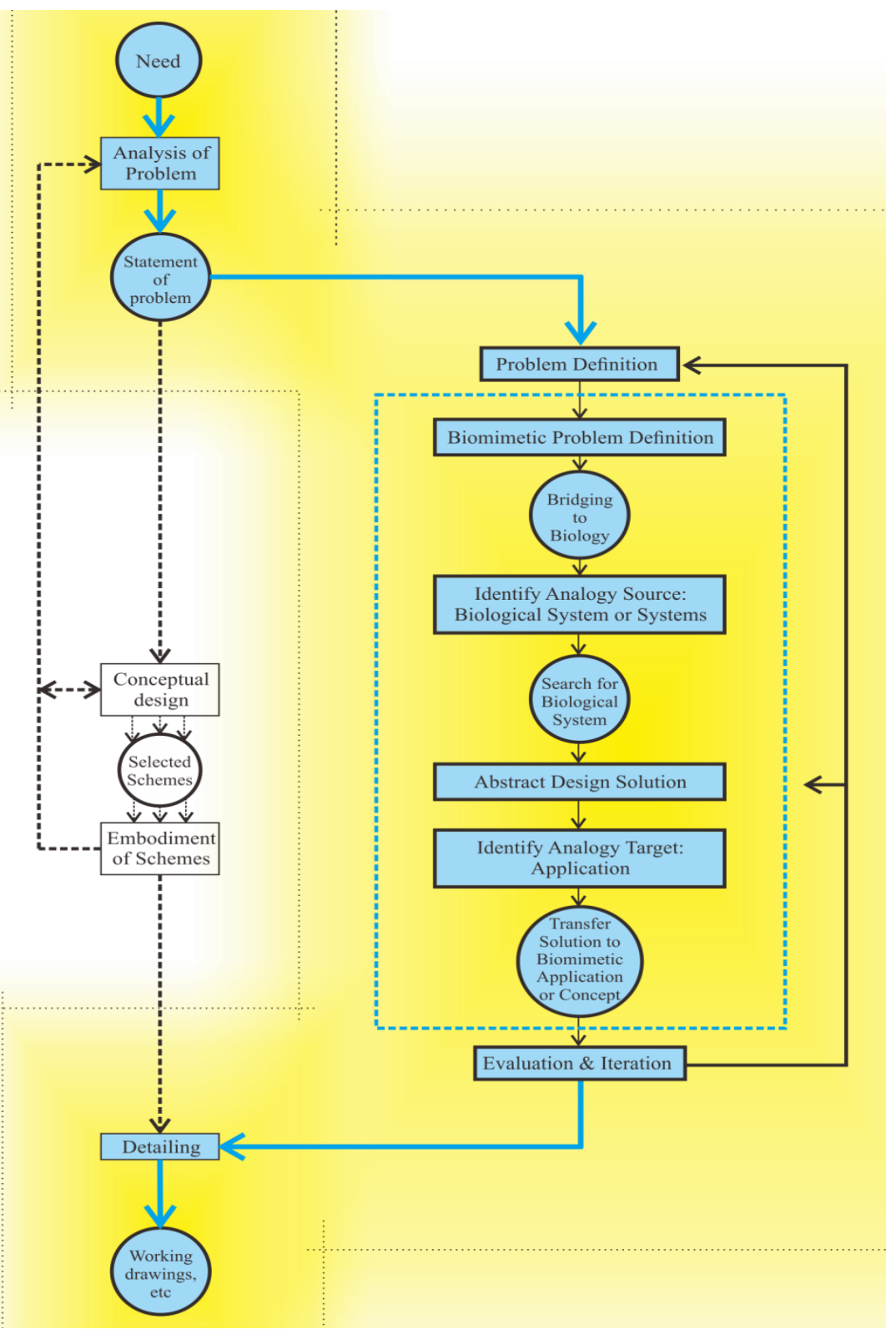

PAWON: Jurnal Arsitektur, Nomor 01 Volume VI, Januari - Juni Tahun 2022, ISSN 2597-7636 


\section{HASIL DAN PEMBAHASAN}

\subsection{Tahap Penelitian}

Proses analisa permasalahan diawali dengan tahap pengumpulan data. Kegiatan pengumpulan data dilakukan dengan proses wawancara pada petugas medis dan pasien penderita tuberkulosis paru di lingkungan Rumah Sakit Paru Surabaya.

Hasil dari kegiatan wawancara berupa kesimpulan masalah yang timbul dalam rumah sakit tuberkulosis paru. Aspek masalah tersebut antara lain:

- Aspek Suhu: Suhu ruangan berada pada kisaran 20-30 derajat celcius.

- Aspek Pencahayaan Alami: Dapat masuk kedalam bangunan untuk membunuh kuman tuberkulosis dan Pencahayaan alami yang masuk kedalam bangunan dapat dikontrol.

\subsection{Tahap Perancangan}

Proses perancangan dilakukan dengan mengikuti metode analogi pada konsep biomimicry untuk mencari solusi permasalahan dengan mempertimbangkan aspek-aspek khusus yang berada di alam.

Tabel 2:

Aplikasi konsep tanaman parasit pada permasalahan Aspek Suhu

Tahapan

\begin{tabular}{|c|c|}
\hline Tahapan & Respon \\
\hline Analisa permasalahan & $\begin{array}{l}\text { Mengurangi peningkatan suhu } \\
\text { bangunan akibat paparan sinar } \\
\text { matahari }\end{array}$ \\
\hline $\begin{array}{l}\text { Analisa permasalahan terkait } \\
\text { aspek biologi }\end{array}$ & $\begin{array}{l}\text { Melindungi selubung bangunan dari } \\
\text { paparan matahari langsung pada area } \\
\text { tertentu }\end{array}$ \\
\hline Identifikasi sumber analogi & $\begin{array}{l}\text { Konsep tanaman parasit dari } \\
\text { ekosistem hutan hujan yang tumbuh } \\
\text { pada tumbuhan lain yang lebih besar }\end{array}$ \\
\hline Abstraksi solusi biologis & $\begin{array}{l}\text { - Memanfaatkan kebiasaan tanaman } \\
\text { parasit yang tumbuh pada media } \\
\text { tanaman lain, sehingga } \\
\text { menciptakan selubung pelindung } \\
\text { pada tanaman obyek media dari } \\
\text { tanaman parasit. }\end{array}$ \\
\hline $\begin{array}{l}\text { Tahapan transfer solusi ke } \\
\text { aplikasi }\end{array}$ & $\begin{array}{l}\text { - } \\
\text { Aplikasi area bangunan yang tidak } \\
\text { memerlukan paparan matahari } \\
\text { - Bagian bangunan yang terpapar } \\
\text { matahari langsung antara lain atap } \\
\text { dan dinding bangunan } \\
\text { - } \quad \text { Bagian dinding bangunan dipilih } \\
\text { untuk aplikasi konsep tanaman }\end{array}$ \\
\hline
\end{tabular}

PAWON: Jurnal Arsitektur, Nomor 01 Volume VI, Januari - Juni Tahun 2022, ISSN 2597-7636 


\begin{tabular}{ll}
\hline & parasit. \\
\hline $\begin{array}{l}\text { Evaluasi dan pengulangan } \\
\text { proses }\end{array}$ & Penentuan media tanam pada \\
& dinding bangunan agar tanaman \\
& tidak merusak dinding bangunan. \\
\hline
\end{tabular}

Sumber: Dokumen Pribadi

Tabel 3:

Aplikasi konsep kelopak bunga dan kulit durian pada permasalahan Pencahayaan Alami

\begin{tabular}{|c|c|c|}
\hline Tahapan & Respon & Respon \\
\hline $\begin{array}{l}\text { Analisa } \\
\text { permasalahan }\end{array}$ & $\begin{array}{l}\text { Mencegah penyebaran bakteri } \\
\text { tuberkulosis di sekitar tapak } \\
\text { yang berpotensi menjangkit } \\
\text { masyarakat sekitar tapak }\end{array}$ & $\begin{array}{l}\text { Peningkatan suhu pada } \\
\text { area jembatan akibat } \\
\text { pencahayaan alami dan } \\
\text { kebutuhan visibilitas. }\end{array}$ \\
\hline $\begin{array}{l}\text { Analisa } \\
\text { permasalahan } \\
\text { terkait aspek } \\
\text { biologi }\end{array}$ & $\begin{array}{l}\text { Dibutuhkan aspek } \\
\text { perlindungan terhadap kuman } \\
\text { tuberkulosis agar tidak } \\
\text { tersebar keluar kawasan klinik } \\
\text { tuberkulosis }\end{array}$ & $\begin{array}{l}\text { Mencegah peningkatan } \\
\text { suhu akibat paparan } \\
\text { sinar matahari dengan } \\
\text { mempertimbangkan } \\
\text { aspek visibilitas ruang. }\end{array}$ \\
\hline $\begin{array}{l}\text { Identifikasi } \\
\text { sumber analogi }\end{array}$ & $\begin{array}{l}\text { Konsep isolasi dari komponen } \\
\text { bunga, yaitu kelopak bunga } \\
\text { yang melindungi komponen } \\
\text { internal bunga dari pengaruh } \\
\text { negatif lingkungan. }\end{array}$ & $\begin{array}{l}\text { Konsep bentuk dari kulit } \\
\text { luar durian yang memiliki } \\
\text { fungsi sebagai pelindung } \\
\text { buah durian terhadap } \\
\text { lingkungan }\end{array}$ \\
\hline $\begin{array}{l}\text { Tahapan transfer } \\
\text { solusi ke aplikasi }\end{array}$ & $\begin{array}{l}\text { - Aspek isolasi pada kelopak } \\
\text { bunga merupakan aspek } \\
\text { perlindungan terhadap } \\
\text { komponen internal bunga. } \\
\text { - Isolasi bangunan digunakan } \\
\text { untuk pembatasan } \\
\text { penyebaran udara yang } \\
\text { mengandung kuman } \\
\text { terhadap lingkungan } \\
\text { sekitar. } \\
\text { - Aliran udara dalam } \\
\text { bangunan diarahkan } \\
\text { menuju paparan matahari } \\
\text { langsung. } \\
\end{array}$ & $\begin{array}{l}\text { - Bentukan kulit durian } \\
\text { memiliki karakter unik } \\
\text { dan dapat } \\
\text { diaplikasikan sebagai } \\
\text { shading bangunan } \\
\text { - Bentukan kulit durian } \\
\text { juga mendukung } \\
\text { visibilitas ruagn } \\
\text { sehingga aplikasi } \\
\text { bentukan pada area } \\
\text { jembatan tidak akan } \\
\text { menggangu } \\
\text { kenyamaan visibilitas }\end{array}$ \\
\hline $\begin{array}{l}\text { Tahapan transfer } \\
\text { solusi ke aplikasi }\end{array}$ & $\begin{array}{l}\text { - Aplikasi konsep pada } \\
\text { massa bangunan } \\
\text { - Massa bangunan mengitari } \\
\text { komponen pusat, sehingga } \\
\text { tercipta barrier. }\end{array}$ & $\begin{array}{l}\text { - Aplikasi pada dinding } \\
\text { jembatan sebagai } \\
\text { shading untuk } \\
\text { mengurangi paparan } \\
\text { sinar matahari pada }\end{array}$ \\
\hline
\end{tabular}

PAWON: Jurnal Arsitektur, Nomor 01 Volume VI, Januari - Juni Tahun 2022, ISSN 2597-7636 
- Aspek perlindungan diwujudkan dengan dinding tinggi disekitar bangunan, sehingga udara yang mengandung kuman akan lebih dahulu terpapar oleh sinar matahari sebelum mencapai kawasan luar. permukaan jembatan

- Bentuk kulit durian memiliki rongga pada bagian bawah, sehingga dapat mendukung aspek visibilitas area jembatan.
Evaluasi dan pengulangan proses
- Konsep isolasi akan menahan udara pada kawasan dan berpotensi meningkatkan penularan di kawasan klinik.

\section{Sumber: Dokumen Pribadi}

\subsection{Aplikasi Konsep Tanaman Parasit Dalam Bangunan}

Aplikasi konsep penggunaan tanaman sebagai wujud dari konsep tumbuhan parasit pada dinding bangunan ditempatkan pada dinding bagian barat bangunan sebagai area paparan sinar matahari dengan intesitas tinggi.

Wujud dari konsep tanaman parasit tersebut adalah penggunaan vertical-garden pada dinding bangunan dengan intensitas paparan matahari yang tinggi.
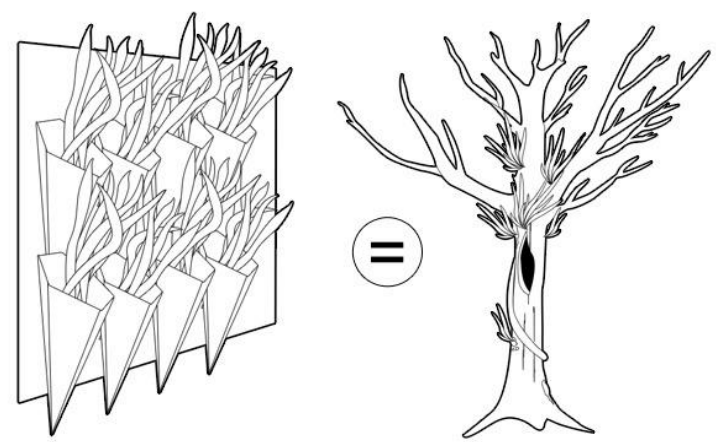

Gambar. 1

Analogi transfer konsep dari tanaman parasit pada bangunan Sumber: Dokumen pribadi 


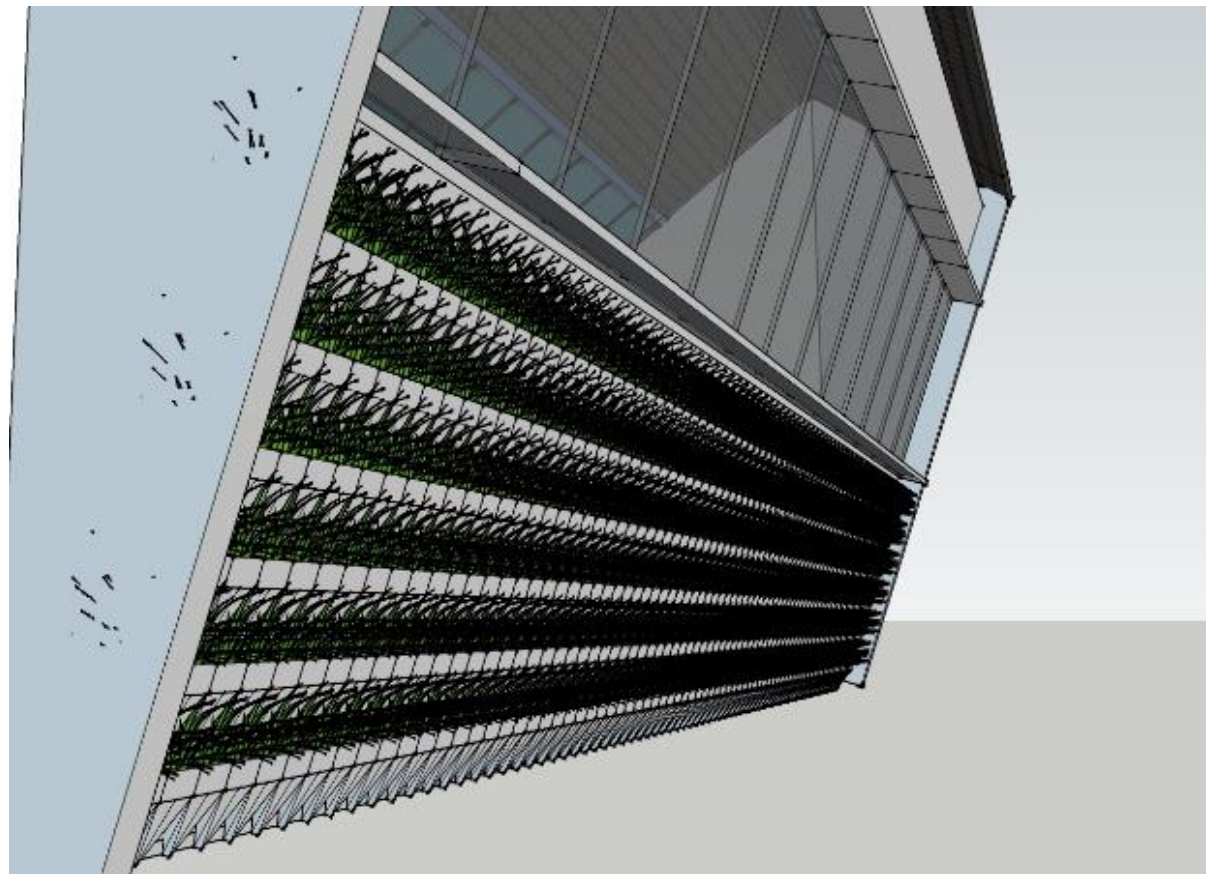

Gambar. 2

Aplikasi konsep tanaman parasit pada dinding bangunan

Sumber: Dokumen pribadi

\subsection{Aplikasi Konsep Kelopak Bunga Dalam Bangunan}

Aplikasi konsep kelopak bunga diwujudkan dalam massa bangunan yang memanfaatkan dinding luar bangunan sebagai barrier antara area internal dari klinik dengan area lingkungan sekitar.

Fungsi barrier tersebut adalah untuk membatasi pergerakan udara yang mengandung kuman di area dalam bangunan, agar tidak bergerak menuju area sekitar. 


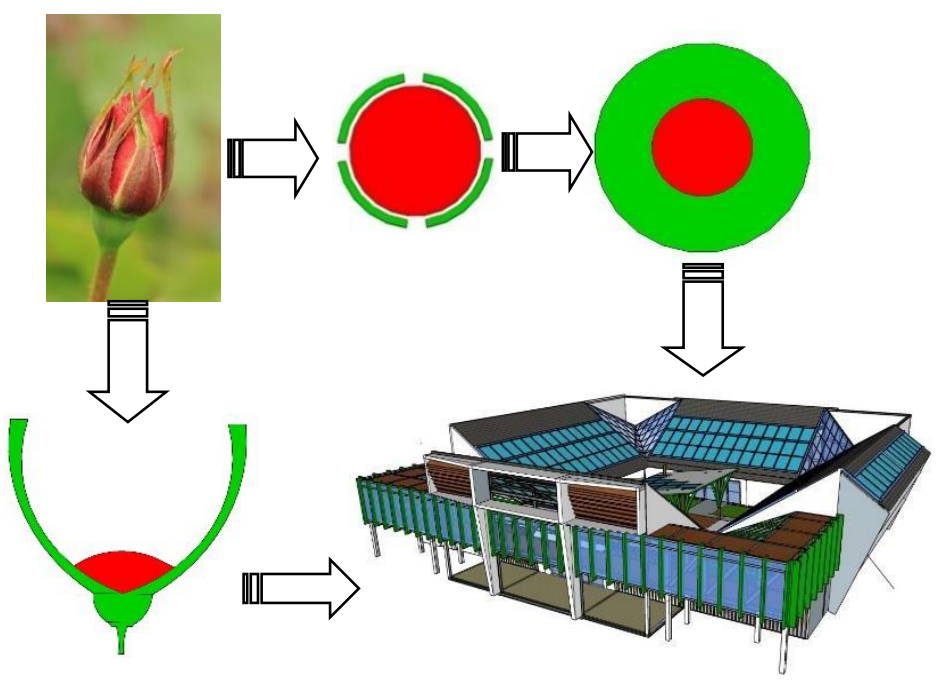

Gambar. 3

Aplikasi konsep kelopak bunga pada massa bangunan Sumber: Dokumen pribadi 

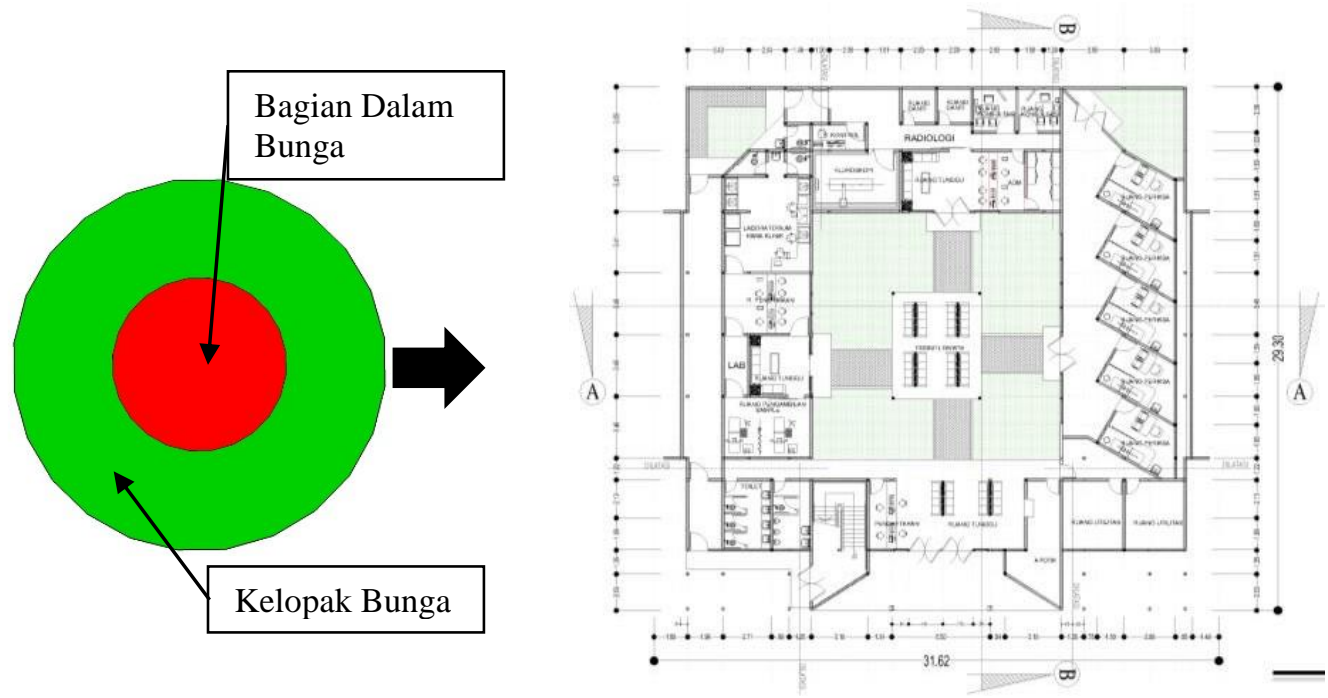

Gambar. 4

Aplikasi konsep kelopak bunga pada denah bangunan

Sumber: Dokumen pribadi

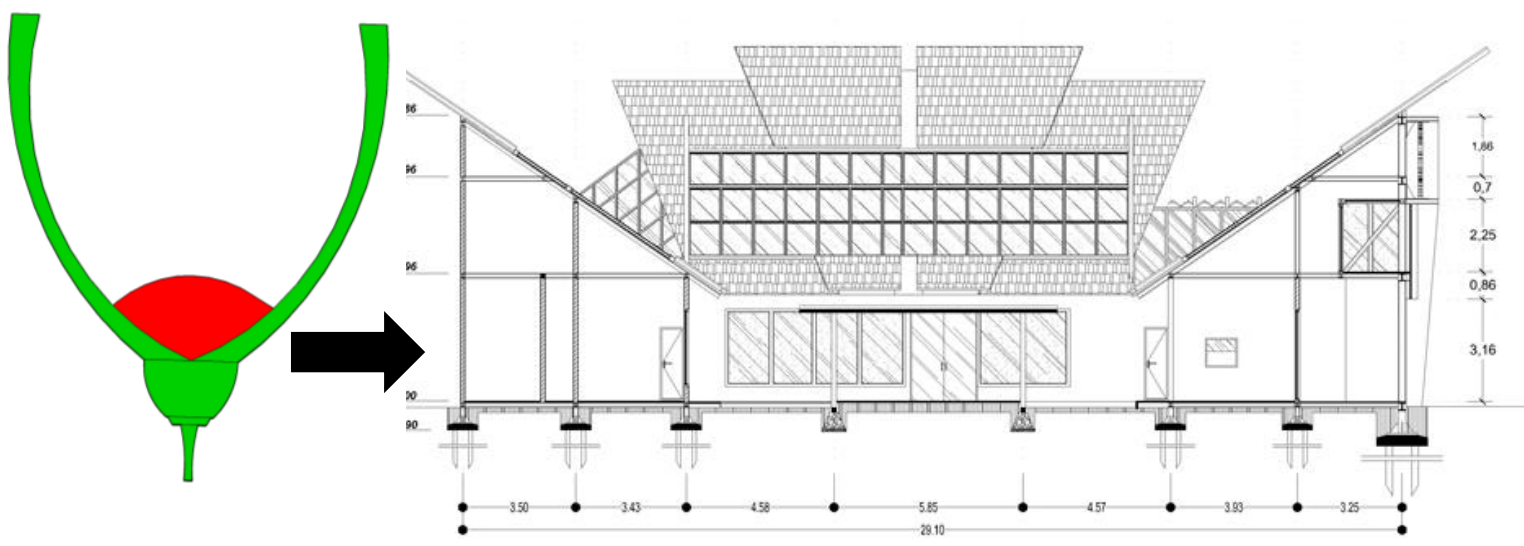

Gambar. 5

Aplikasi konsep kelopak bunga pada potongan bangunan

Sumber: Dokumen pribadi

PAWON: Jurnal Arsitektur, Nomor 01 Volume VI, Januari - Juni Tahun 2022, ISSN 2597-7636 


\subsection{Aplikasi Konsep Kulit Durian Pada Bangunan}

Penggunaan konsep kulit durian pada bangunan diwujudkan dalam bentuk Shading dengan pola kulit durian. Pola tersebut diletakkan pada area depan bangunan yang memerlukan fungsi visibilitas pada bangunan namun tidak diharapkan adanya peningkatan suhu akibat aspek visibilitas tersebut. Pola kulit durian memberikan efek peneduh tanpa mengganggu visibilitas pada area tersebut.

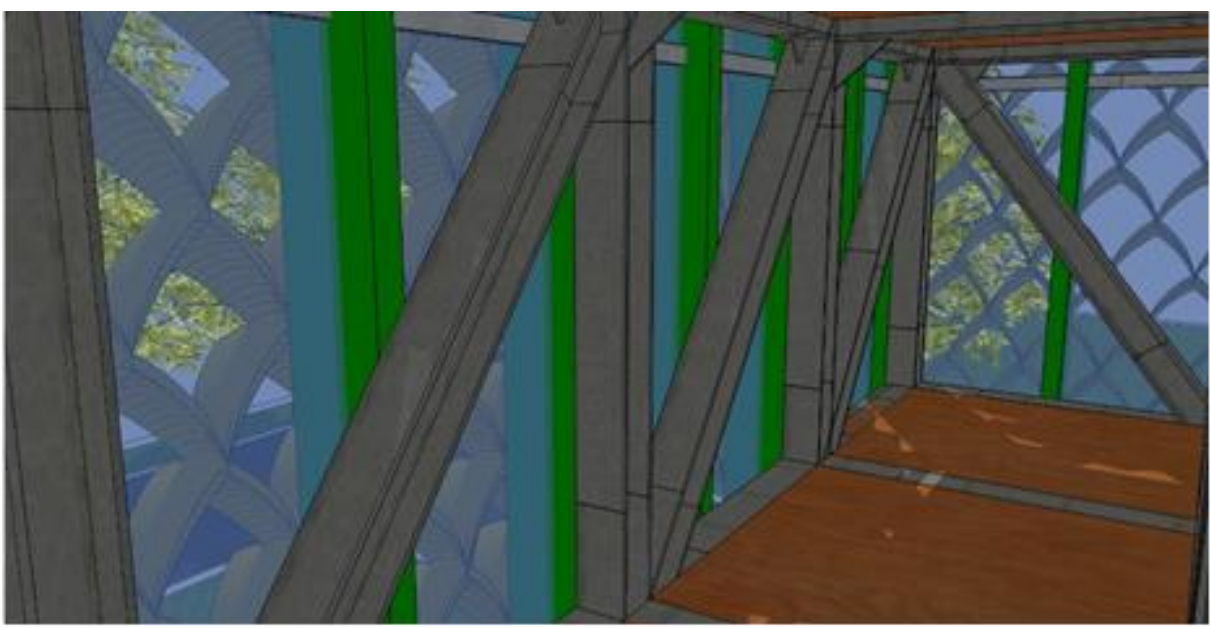

Gambar. 6

Aspek visibilitas pada pola kulit durian pada bangunan Sumber: Dokumen pribadi

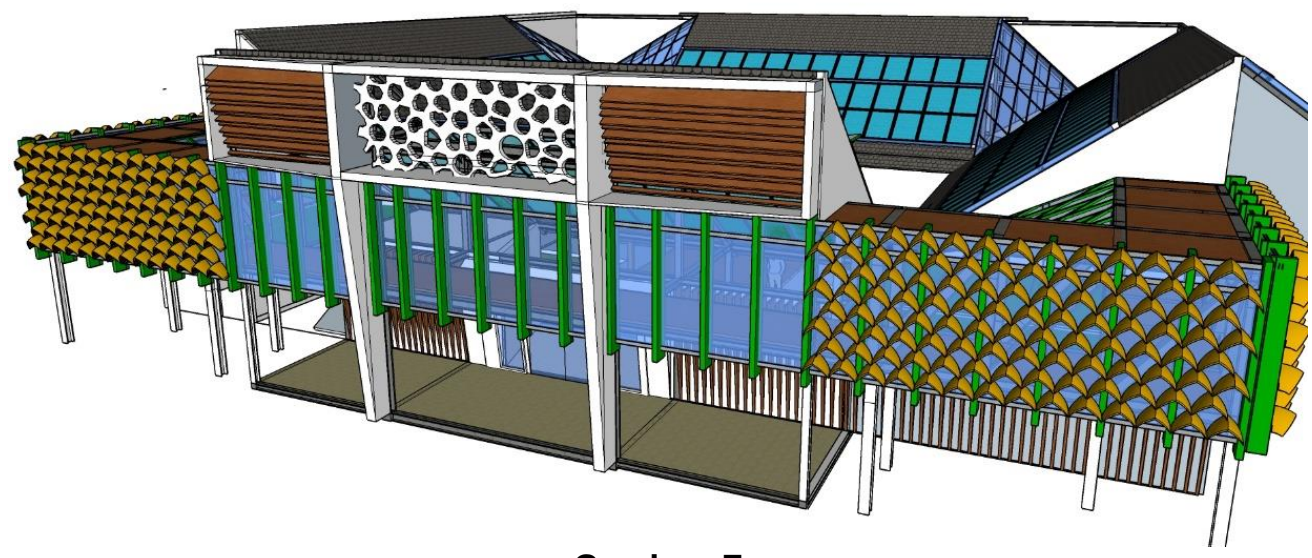

Gambar. 7

Aplikasi pola kulit durian pada bangunan

Sumber: Dokumen pribadi

PAWON: Jurnal Arsitektur, Nomor 01 Volume VI, Januari - Juni Tahun 2022, ISSN 2597-7636 


\section{KESIMPULAN}

Aplikasi konsep alam pada bangunan melalui metode campuran deskriptif dan analogi mempu memunculkan permasalahan yang timbul dalam bangunan serta mencari solusi dari masalah tersebut.

Penerapan konsep tanaman parasit pada bangunan untuk mengurangi penurunan suhu secara pasif dapat diaplikasikan pada dinding bangunan yang memiliki area paparan sinar matahari yang maksimal, sehingga dapat mengurangi kenaikan suhu secara pasif. Perlu dikembangkan kembali terkait jenis tanaman yang digunakan dalam konsep tersebut, khususnya tanaman yang dapat bertahan terhadap paparan sinar matahari langsung serta memiliki kemudahan dalam segi perawatan.

Aplikasi kelopak bunga pada massa bangunan memberikan efek barrier yang dapat menghambat pergerakan udara dari area dalam bangunan ke area luar bangunan, sehingga dapat mengurangi penyebaran virus tuberkulosis pada masyarakat sekitar bangunan.

Aplikasi pola kulit durian pada bangunan dapat memberikan aspek visibilitas dan aspek peneduh pada area depan bangunan. Pola kulit durian saling menyatu satu dengan yang lain sehingga dapat mendukung kekuatan shading tersebut ketika di pasang pada bangunan.

\section{DAFTAR PUSTAKA}

Aditama, T.Y. (1994), Tuberkulosis paru: Masalah Dan Penanggulangan, UI Press, Jakarta, hal. 1-29

Benyus, J.M (1997), Biomimicry: Innovation Inspired by Nature, Morrow, New York.

Cohen, Y.H dan Reich, Y., (2016), Biomimetic Design Method for Innovation and Sustainability, Springer International Publishin, Switzerland.

Cross, N, (1994), Engineering Design Methods: Strategies for Product Design, John Wiley\&Sons, Ltd., New Jersey.

Curry International Tuberculosis Center, (2011), Tuberculosis Infection Control: A Practical Manual for Prefenting TB, Curry International Tuberculosis Center, San Francisco.

Depkes RI. (2002), Pedoman Nasional Penanggulangan Tuberkulosis, Departemen kesehatan, Jakarta.

Gultom ZA., Yahya K., (2012), Pemetaan Penyakit Tuberkulosis Di Kota Surabaya tahun 2012, Analisa Statistik Multivariat, Jurusan Statistika, ITS, Surabaya.

Menteri kesehatan, R.I., (2014), Peraturan Menteri Kesehatan Republik Indonesia Nomor 9 tahun 2014 Tentang Klinik, Departemen Kesehatan, Jakarta.

World Health organization (2016), Global Tuberculosis Report 2016, WHO, Switzerland.

Zari, M.P., (2007), Biomimetic Approaches to Architectural Design for Increased Sustainability, Sustainable building conference, Aukland.

PAWON: Jurnal Arsitektur, Nomor 01 Volume VI, Januari - Juni Tahun 2022, ISSN 2597-7636 